\title{
Relationship between the value of the estrous detector measurement result and serum progesterone level in Etawa crossbred goats after estrous synchronization
}

\section{Hubungan antara nilai hasil pengukuran detektor estrus dengan progestron serum pada kambing Peranakan Etawa setelah sinkronisasi estrus}

\author{
Annisa Lita Triagil', Ismudiono Ismudiono ${ }^{2 *}$, Boedi Setiawan ${ }^{3}$, Tita Damayanti Lestari2 ${ }^{2}$, \\ Abdul Samik², Budi Utomo \\ ${ }^{1}$ Student, ${ }^{2}$ Department of Veterinary Reproduction, ${ }^{3}$ Department of Veterinary Clinic, \\ Faculty of Veterinary Medicine, Universitas Airlangga \\ *Corresponding author, e-mail: ismudiono@fkh.unair.ac.id
}

\author{
Open access under CC BY - SA license, Doi : 10.20473/ovz.v9i3.2020.82-85 \\ Received September 24 2020, Revised November 18 2020, Accepted December 62020 \\ Published online December 62020
}

\begin{abstract}
This study was conducted to determine the relationship between the estrous detector's reading value (Draminski ${ }^{\circledR}$, Dramiński S.A, Poland) and serum progesterone levels on Etawa crossbred does. Eighteen healthynon-prehnant Etawa crossbreds does weighing 20-25 kg, in their first parity were used in this study. The does were divided equally into two groups. In the two groups, the does were synchronized their estrus by means of intramuscular and intravulvar injection of $7.5 \mathrm{mg}$ prostaglandin Fa (PGF2a) twice in 11-day intervals. After the second injection, the estrous detector value measurement, visual observation of the estrus sign, and blood sampling were conducted for five days. The blood sample was processed into the serum to examine for progesterone levels by ELISA. The data analysis was using the simple correlation method on SPSS type 23 for windows. The result showed that a positive relationship $(\mathrm{p}<0.05)$ with coefficient correlation $(\mathrm{r})$ was 0.609 between the values of the estrous detector measurement with serum progesterone levels. It could be concluded that the estrous detector's low value indicates that the Etawa crossbred was in the estrus phase and followed by the decreasing of progesterone level but not reaching the basal level.
\end{abstract}

Keywords: estrous detector, Etawa crossbred, progesterone level, synchronization

\section{INTRODUCTION}

Etawa crossbred goat is crossed from the Jamnapari from Etawa district of India's Uttarbal region with Kacang goat, a local goat of Indonesia. Etawa crossbred goats have higher milk and meat yields than local goats (Prajoga, 2007). Breeders in improving the quality of livestock need to have artificial insemination. Determination of the right estrous time is essential for artificial insemination (Omontese, 2018).

Draminski's estrous detector is a device that can help detect estrous. This tool shows figures that describe the quality of vagina mucus through electrical resistance (Izabela et al., 2007; Meydilasari et al., 2020). According to Draminski (2009), a goat is declared estrus if an estrous detector is inserted to examine vaginal mucus showing a number close to 200. Synchronization of estrus was carried out on livestock to obtain estrus simultaneously. The synchronization that is commonly used is prostaglandin (PF2 $\alpha$ ) (Ismudiono et al., 2009). The prostaglandin mechanism $(\mathrm{F} 2 \alpha)$ as a hormone produced by the endometrium is to lyse the corpus luteum. Lysis of CL resulted in the normal cycle's return to being effective at 
inducing estrus (Saoeni, 2008). Progesterone is one of the essential hormones in reproduction, secreted by the luteal cells (Atabany et al., 2001). Progesterone levels decreased during estrus on day 0 to day 21 (Siregar, 2009). The decreased progesterone levels in the estrous cycle are due to the corpus luteum regressed (Sunendar et al., 2008).

\section{MATERIALS AND METHODS}

Eighteen, healthy, non-pregnant Etawa Crossbred does, in their first parity, weighing 20-25 kg were used for the study. Does were synchronized their estrus using $7.5 \mathrm{mg}$ PGF $2 \alpha$ (Enzaprost) twice in 11 days intervals. The does were divided equally into two groups. In the first group, the does were injected intramuscularly (IM). Meanwhile, the second group was injected intravulva (IV). After the second injection, the estrous detector value measurement, visual observation of estrus signs, and blood sampling were conducted for five concequtive days.

Vaginal mucus resistance was examined using Draminski estrous detector the following day after the second PGF2 $\alpha$ injection. Vaginal mucus resistance was measured using an estrous detector, which is initiated by applying lubricant to the vaginal probe. A vaginal probe, which was equipped with electrodes, was inserted around three-quarters of the vagina depth, then the value was recorded. Simultaneously, with the estrous detector value measurement, the estrus sign was observed by bringing the female goat closer to the male goat cage. The three main signs observed were the red color of the vaginal mucous membrane, the amount of cervical mucus, and tail position (up or down). Blood samples were taken from the jugular vein using venoject and vacuum plain tubes. Then the vacuum tube was tilted for 1 hour until a clear coloured serum appeared. Tubes were then centrifuged at $3000 \mathrm{rpm}$ for 15 minutes. Afterward, serum was placed in Eppendorf tubes and stored in a $-20^{\circ} \mathrm{C}$ freezer until the level of progesterone was analyzed with ELISA (Goat Progesterone, PROG ELISA KIT, Cat. MBS704614).

\section{Ethics}

This study was approved ethically by the Animal Care and Use Committee (ACUC) Faculty of Veterinary Medicine, Universitas Airlangga, with ethical clearance No.2.KE.143. 07.2019.

\section{RESULT}

The average value of mucus resistance after the second PGF2a injection can be seen in Table 1. Two out of the nine does in each group (intramuscular and intravulvar injection) exhibited obvious signs of estrus including reddish vaginal mucous membrane, plenty of cervical mucus, and tail up (Table 2). Serum progesterone level is presented in Tabel 3.

Table 1 The value of the estrous detector measurement result of Etawa crossbred goat after the second PGF2a injection.

\begin{tabular}{lccccc}
\hline & day-1 & day-2 & day-3 & day-4 & day-5 \\
\hline IM & $347.78 \pm 136.91$ & $353.33 \pm 135.46$ & $296.67 \pm 134.07$ & $325.56 \pm 83.98$ & $353.33 \pm 97.72$ \\
IV & $348.89 \pm 116.24$ & $317.78 \pm 77.59$ & $267.78 \pm 82.28$ & $283.33 \pm 97.08$ & $307.78 \pm 63.20$ \\
\hline
\end{tabular}

$\mathrm{IM}=$ intramuscular $\mathrm{PGF} 2 \alpha$ injection; $\mathrm{IV}=$ intravulvar $\mathrm{PGF} 2 \alpha$ injection; replicates $=9$ 
Table 2 Estrus sign based on visual observation of Etawa crossbred does after the second PGF2a intramuscular and intravulvar injection

\begin{tabular}{|c|c|c|c|c|c|}
\hline & day-1 & day-2 & day-3 & day-4 & day-5 \\
\hline \multicolumn{6}{|l|}{$\begin{array}{l}\text { intramuscular } \\
105\end{array}$} \\
\hline Vmm & pale & reddish & reddish & reddish & pale \\
\hline $\mathrm{Cm}$ & slight & moderate & a lot & a lot & slight \\
\hline tail & - & up & up & down & down \\
\hline \multicolumn{6}{|l|}{125} \\
\hline $\mathrm{Vmm}$ & pale & pale & reddish & reddish & pale \\
\hline $\mathrm{Cm}$ & slight & moderate & a lot & a lot & moderate \\
\hline tail & - & - & up & down & down \\
\hline \multicolumn{6}{|l|}{ intravulvar } \\
\hline $\mathrm{Vmm}$ & reddish & pale & reddish & pale & pale \\
\hline $\mathrm{Cm}$ & moderate & slight & a lot & a lot & slight \\
\hline tail & - & - & up & down & down \\
\hline \multicolumn{6}{|l|}{324} \\
\hline Vmm & reddish & reddish & reddish & pale & pale \\
\hline $\mathrm{Cm}$ & moderate & a lot & a lot & slight & moderate \\
\hline tail & - & up & up & down & down \\
\hline
\end{tabular}

$105,125,285,324=$ does number; Vmm= vaginal mucous membrane; $\mathrm{Cm}=$ cervical mucus

Table 3 Serum Progesterone level $(\mathrm{ng} / \mathrm{mL})$ of Etawa crossbred does after the second PGF2a intramuscular and intravulvar injection

\begin{tabular}{cccccc}
\hline does \# & day-1 & day-2 & day-3 & day-4 & day-5 \\
\hline IM $(\mathrm{n}=2)$ & & & & & \\
105 & 11.106 & 1.391 & 1.809 & 1.589 & 1.944 \\
125 & 5.269 & 0.865 & 1.162 & 1.222 & 1.373 \\
$\mathrm{X} \pm \mathrm{SD}$ & $8.19 \pm 4.13$ & $1.13 \pm 0.37$ & $1.49 \pm 0.46$ & $1.41 \pm 0.26$ & $1.66 \pm 0.40$ \\
$\mathrm{IV}(\mathrm{n}=2)$ & & & & & \\
285 & 1.006 & 1.609 & 3.701 & 1.787 & 1.664 \\
324 & 1.085 & 1.139 & 1.599 & 1.685 & 1.421 \\
$\mathrm{X} \pm \mathrm{SD}$ & $1.05 \pm 0.06$ & $1.13 \pm 0.37$ & $2.65 \pm 1.49$ & $1.74 \pm 0.07$ & $1.54 \pm 0.17$ \\
\hline
\end{tabular}

$\mathrm{IM}=$ intramuscular PGF2 $\alpha$ injection; IV= intravulvar PGF2 $\alpha$ injection

\section{DISCUSSION}

The Draminski Estrous detector shows a lower number (around 200) in estrous onset on day 0-3 and had an increase after estrous (Setiawan, 2012). On the 3rd day, the female begins to reddish vagina mucous membrane, a lot of cervical mucus, tail up (Table 2) and mounted the other goat, followed by a thick and clear discharge from the vulva (Davilia et al., 2018; Ridlo et al., 2018 and Tanjung et al., 2015).
The device's electrical current resistance causes the estrous detector measurement results at the estrous phase. This is due to changes in the composition in the vagina; that is, the amount of mucus that increases (Balumbi et al., 2019, Meydilasari et al., 2020). The composition contained in vaginal mucus after the second PGF2a injection consists of sodium, potassium, and ions, which are electrolyte and have conductivity (Tsilinggani et al., 2001), so that the higher the volume or number of ions in the vaginal mucus, the lower electrical resistance will occur (Verma et al., 2014). The 
estrous detector measurement result has decreased in the estrous phase and can be caused by the hormone estrogen. The vaginal vasodilation causes an increase in the mucus of electrolyte ions and has a relatively high conductivity so that the resistance to electrical current is low and the value of the estrous detector decreases (Kitwood et al., 1993).

In this study, the serum progesterone level of Etawa crossbred goat at the estrus phase was $1.49 \pm 0.46$ to $2.65 \pm 1.49 \mathrm{ng} / \mathrm{mL}$. It was higher compared to $0.083 \pm 0.15 \mathrm{ng} \mathrm{mL}$ of day 0 and $0.084 \pm 0.11$ of Etawa-Saanen crossbred goats progesterone level (Sitarasemi et al., 2017). The progesterone levels in the estrous phase are influenced by several factors, including nutrition (Tanaka et al., 2003), unreported corpus luteum, BCS, postpartum state, lactation, and the presence of males (McDonald et al., 2014; Suharto et al., 2008; Khanum et al., 2006; Totti, 2009 ).

The high levels of progesterone after the synchronization of estrous in this research might be caused by nutrition. The goats fed with low nutrition have increased levels of progesterone in the estrous to the luteal phase. Nutrition plays a vital role in reproduction. Low nutrition can cause the hormones gonadotropin and $\mathrm{LH}$ to be secreted in small amounts, where they play an essential role in stimulating the ovaries for ovulation (McDonald et al., 2014).

High progesterone levels during the estrous phase can occur as a result of postpartum. Goats in $27.9 \pm 14$ days postpartum show $2.1 \mathrm{ng} / \mathrm{ml}$ on day 0 to third (Khanum et al., 2008). Progesterone level in the luteal phase of postpartum does ranged from 2.6 to $5.4 \mathrm{ng} / \mathrm{mL}$ (Gaafar et al., 2005). In the IM PGF2Fa injection Group, does numbers 105 and 125 on the first day showed high levels of progesterone and decreased on the second day. The other two goats (number 285 and 324) show a progesterone fluctuation after IV PGF2Fa injection. It means they were in deference stages of the cycle and might be the does were not affected by the hormone injection. This is due to the first day of the second PGF2Fa injection, the corpus luteum has not been regressed. The second day after the second injection, the corpus luteum starts to lysis and decreases progesterone concentration (Satiti et al., 2014, Lestari dan Ismudiono, 2014).

Adequate nutrition for goats should be given a diet containing $60-75 \%$ TDN with 12 $17 \%$ protein content. Malnutrition of goats affects the inadequate response of estrous synchronization (Paula et al., 2005). The interval of removal of the sponge in the synchronization and the ovulation rate tend to depend on the amount of body mass lost during malnutrition (Lozano et al., 1997). The less than optimal response to the synchronization causes the corpus luteum to undergo an imperfect regression, where PGF2a should lyse the corpus luteum, so that blood flow in CL decreases dramatically, followed by a decrease in progesterone (Towle, 2002). The imperfect regression corpus luteum causes high levels of progesterone

There was a positive relationship $(\mathrm{r}=0.609$, $\mathrm{p}<0.05)$ between the value of the estrous detector measurement result with progesterone levels. It means a high progesterone level follows a high estrous detector value. The estrous detector's low value indicates that the goat has estrus followed by a decrease in progesterone levels even though it is not in a basal state. The goat, which shows usual symptoms of estrous with progesterone levels above the normal level of estrous phase, is possibly caused by a good body condition score. The animal with good health shows a normal cycle of reproduction (Lestari and Ismudiono 2014). Nevertheless, some goats might behave good estrous but not accompanied by LH surges. The absence of LH surge can be caused by an imperfect corpus luteum and finally showed lower progesterone level (Suharto et al., 2008).

\section{CONCLUSION}

In conclusion, there is a positive relationship between the value of the estrous detector and progesterone levels. This relationship has a correlation value of 0.609 and a significant value (2-tailed) of $0.004<0.05$ (positive).That means the estrous detector's low value indicates the Etawa crossbred goats have estrous and progesterone levels and decrease but do not reach the basal level. 


\section{ACKNOWLEDGEMENT}

The authors grateful to UPT HMT Singosari Malang's head and staff, who have given permission and assistance during the research.

\section{REFERENCES}

Atabany A, Abdulgani IK, Sudono A, Mudikdjo K. 2001. Performa Produksi, Repro duksi dan Nilai Ekonomis Kambing Peranakan Etawa di Peternakan Barokah. Media Peternakan 24: 1-7.

Balumbi M, Setiadi MA, Supriatna I. 2019. Response and Characteristics of Estrous after Estrous Synchronization with Cloprostenol in Friesian Holstein Cow. Acta Vet Indonesiana 7: 29-36.

Davilia FS, Del Bosque Gonzales AS, Barragá HB. 2018. Reproduction in Goat. intechopen.70003. http://dx.doi.org/10.5772/

Gaafar KM, Gabr MK, Teleb DF. 2005. The hormonal profile during the estrous cycle and gestation in Damascus goats. J Small Rumin Res. 57: 85-97.

Ismudiono I, Anwar H, Srianto P, Madyawati SP, Samik A, Safitri E. 2009. Buku Ajar Fisiologi Reporduksi pada Ternak. Airlangga University Press. Surabaya.

Izabela M, Angela S, Paula P, Laura U. 2007. Researchs on the Electrical Resistence of Cervical Mucus in Cows . lucrări ştiinţifice zootehnie şi biotehnologii. Timisoara 40:568-57.

Khanum SA, Hussain M, Kausar R. 2006. Assessment of Reproductive Parameters in Female Dwarf goat (Capra hircus) on The Basis of Progesterone Profile. J Anim Rep Sci. 102: 267-75.

Khanum SA, Hussain M, Kausar R. 2008. Progesterone and Estradiol Profile During Estrous Cycle and Gestation in Dwarf Goat (Capra Hiracus). Pakistan Vet J. 28: 1-4.

Kitwood SE, Philips CJC, Weise M. 1993. Use of a Vaginal Mucus Impedance Meter to Detect Estrus. J. Theriogenology 40: 55969.

Lestari TD dan Ismudiono I. 2014. Ilmu
Reproduksi Ternak. Airlangga University Press. Surabaya.

Lozano JM, Abecia JA, Forcada F, Zazaraga L, Alfaro B. 1997. Effect of Undernutrition on The Distribution of Progesterone in The Uterus of Ewe During The Luteal Phase of The Estrous Cycle. Theriogenology 49: 539-46.

McDonald P, Edwards RA, Greenhalgh JFD, Morgan CA, Sinclair LA, Wilkinson RG. 2010. Animal Nutrition. Seventh Edition. Pearson. London. 388.

Meydilasari NI, Hernawati T, Hidanah S, Lestari TD, Safitri E, Sardjito T, Ismudiono I. 2020. Hubungan antara skor hasil bacaan estrous detector dengan gambaran sitologi vagina sebagai parameter penentuan estrus pada kambing. Ovozoa J Anim Reprod. 9: 711.

Omontese BO. 2018. Estrus Synchronization and Artificial Insemination in Goats.Open access peer-reviewed chapter.

https://doi.org/10.5772/intechopen.74236

Paula NRO, Galeati G, Teixeria DIA, Lopes Junior ES, Freitas VJF, Rondina D. 2005. Respinsiveness to Progestagen-eCGCloprostenol Treatment in Goat Food Restricted for Long Period and Refed. Reprod Domest Anim. 40: 108-10.

Prajoga SBK. 2007. Effect of In-Breeding on Estimation of Respon to Selection of Weaning Weight of Etawa Cross Bred (PE), in The Small Population. J Anim Sci Padjadjaran Univ. 7: 170-8. https://doi.org/10.24198/jit.v7i2.2254.

Ridlo MR, Ummami R, Dalimunthe NWY, Ramadani D, Prihanani NI, Andityas M, Widi TSM. 2018. Profil vulva dan suhu tubuh kambing Peranakan Etawa pada sinkronisasi estrus menggunakan Medroxy Progesterone Acetate dan suplementasi Zinc (Zn). J Nasional Teknologi Terapan. 2:198-211.

Saoeni R. 2007. Efek pemberian Prostaglandin F2 $\alpha$ secara intra vaginal spons (IVS) dan intra muskular (IM) terhadap peningkatan kinerja reproduksi domba. J Animal Production 9: 129-34. 
Satiti D, Triana IN, Rahardjo AP. 2014. Pengaruh Penggunaan Kombinasi Progesteron (Medroxy Progesterone Acetate) dan Prostaglandin (PGF2 $\alpha$ ) Injeksi Terhadap Persentase Estrus dan Kebuntingan pada Domba Ekor Gemuk. Veterinaria Medika. 7:126-33.

Setiawan KD. 2012. Karakteristik Lendir Vagina Kambing Peranakan Etawa (PE) Setelah Sinkronisasi berahi dengan Prostaglandin [Skripsi]. Fakultas Kedokteran Hewan. Institut Pertanian Bogor. 10. http://repository.ipb.ac.id/handle/123456 789/60909

Siregar TN. 2009. Estrogen and Progesterone Profile in Aceh Local Goat Estrous Cycle. J Ked Hewan 3: 240-47.

Sitarasemi PI, Widyobroto BP, Bintara S, Widayati DT. 2017. Progesterone and Biochemical Profile of Ettawa-Saanen Crossbread Goat in Turri Area Yogyakarta-Indonesia. Int $\mathrm{J}$ Dairy Sci. 12: 289-94.

Suharto K, Junaidi A, Kusumawati A, Widayati DT. 2008. Comparison of Fertility of Etawa Crossbred Goats in Low versus Ideal Body Condition Score after Estrus Synchronization and Artificial Insemination. Media Kedokteran Hewan 24: 49-54.

Sunendar S, Widayati DT, Junaidi A. 2008. Profil Hormon Progesteron dan Estrogen pada Kambing Peranakan Etawah yang Disinkronisasi Estrus dengan Implan
Controlled Internal Drug Release. Buletin Peternakan 32: 26-37.

Tanaka TT, Yamaguchi H, Kamomae H, Kaneda Y. 2003. Nutritionally Induced Body Weight Loss and Ovarian Quiescence in Shiba Goats. J Reprod Dev. 49: 113-9.

Tanjung AD, Setiatin ET, Samsudewa D. 2015. Level of estrogen hormone and estrus performance of different postpartum estrus of Jawa Randu goat. J Indonesian Trop Anim Agric. 40: 87-92.

Totti T. 2009. Studi hubungan hormon Progesteron dengan jumlah korpus luteum pada kambing. jurnal ilmiah aplikasi isotop dan radiasi 5: 43-51.

Towle TA, Tsang PCW, Milvae RA, Newbury MK, McCracken JA. 2002. Dynamic In Vivo Changes in Tissue Inhibitors of Metalloproteinases 1 and 2, and Matrix Metalloproteinases 2 and 9, During Prostaglandin F2a-Induced Luteolysis in Sheep. Biol Reprod. 66:1515-1521.

Tsilingianni TH, Karagianidis A, Brikas P, Saratis PH. 2001. Physical Properties of Cervical Mucus During Normal and Induced (Progesterone and/or PGF2a). Theriogenology 55: 629-40.

Verma KK, Prasad S, Kumaresan A, Mohanty TK, Layek SS, Patbandha TK, Chand S. 2014. Characterization of PhysicoChemical Properties of Mucus in Relation to Parity and Conception Rate in Murrah Buffaloes. Vet world 7: 467-71. 